\title{
The Rule of the Gun
}

\section{Human Rights Abuses and Political Repression in the Run-up to Afghanistan's Presidential Election}

\author{
A Human Rights Watch Briefing Paper \\ September 2004
}

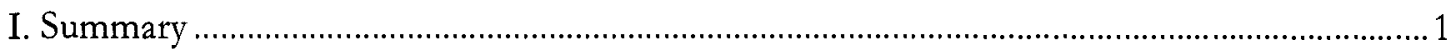

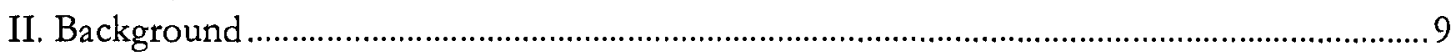

III. Threats and General Political Repression............................................................................15

Regional Problems........................................................................................................................ 16

Security of Presidential Candidates .......................................................................................... 35

Structural Electoral Problems ....................................................................................................

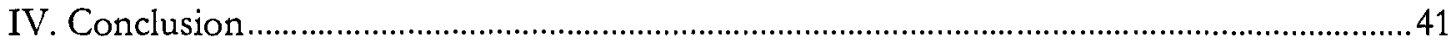

V. Recommendations ........................................................................................................4

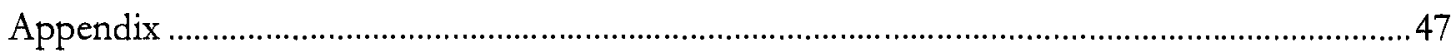
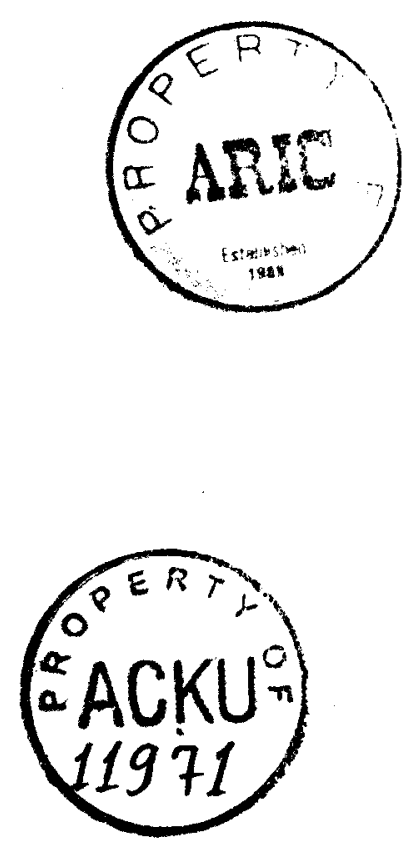


\section{Summary}

In politics bere today whatever the gunmen want ultimately bappens. We don't know what kind of democracy this is.

-Political organizer, Jalalabad, May 31, 2004

On October 9, 2004, Afghanistan will hold its first-ever national election. Voters will choose a president for a five-year term. The election could be prove to be a historic event for a country that has, over the last twenty-five years, suffered Soviet occupation, civil war, failed governance, severe repression of women, and the vicious rule of the Taliban. The prospect of a future dictated by ballots, and not bullets and bombs, is a cause for great hope. Taliban forces and other armed anti-government groups are still trying to disrupt the process by targeting election workers and election sites for attack, and some areas in the south and southeast remain highly unstable. Still, election officials maintain that overall preparations are on track. Afghan and international leaders are vowing that elections will be successful.

The reality, however, is more complex-and worrisome. Parliamentary elections have been postponed until 2005 because of security concerns and logistical problems. Major security and human rights problems persist, and seriously endanger the country's future.

Political repression by local strongmen is the principal problem. Throughout the country, militarized political factions-militias and remnants of past Afghan military forces who came into power in the wake of the Taliban's defeat-continue to cement their hold on political power at the local level, using force, threats, and corruption to stifle more legitimate political activity and dominate the election process. Independent political organizers unaffiliated with factions or their militia forces are facing death threats and harassment and are struggling just to organize. Some politically active Afghan men and women, potential leaders who would otherwise be eager to take part in the political life of their country, have instead already opted out of the process, or are very cautious in their activities, literally afraid for their lives. Voters in many rural areas have already been told by warlords and regional commanders how to vote and, given the general political repression and unfamiliarity with democratic processes, are likely to obey. Women, both as voters and as political actors, remain marginalized.

Political instability also persists, caused by ongoing conflicts between armed factions competing against each other for power, and the continuing insurgency against the government of President Hamid Karzai. In some areas-like the western city of Herat-the political situation recently descended into violence, and still remains tenuous 
and unpredictable. In other areas-like Zabul and Kunar province-whole districts are essentially war zones where U.S. and Afghan government forces engage in military operations against Taliban and other insurgent groups.

Afghans in the south and southeast in particular are facing intimidation from Taliban and insurgent groups, who threaten residents not to take part in the elections, and continue to carry out attacks on the election process and engage militarily with U.S. and Afghan government troops.

While many observers inside and outside Afghanistan continue to focus on the Taliban as the main threat to human rights and political development, in most parts of the country Afghans told Human Rights Watch that they are primarily afraid of the local factional leaders and military commanders-not the Taliban insurgency. Far from a Taliban problem, most Afghans tell us that their main fear is of jangsalaran-the Dari and Pashto word for "warlords." They say that Afghanistan has a warlord problem-a problem with military factions dominating government and national institutions, including local governments and the army, police, and intelligence services.

And as many Afghans say, this warlord problem is ultimately a human rights problem. Almost all of the warlord factions are implicated in past and ongoing human rights abuses and political repression, much of which Human Rights Watch has documented in previous reports.

This report, based on research conducted by Human Rights Watch from June through September 2004, details the scope of this ongoing human rights problem in the context of the October 9 election. It outlines specific intimidation tactics used by warlord factions to undermine the organization of political groups, and describes how some presidential and vice-presidential candidates have already faced threats and other harassment. The report shows a pattern of threats made against Afghan journalists and potential candidates for next year's parliamentary and local elections. It concludes that voters in many rural areas have not received adequate information or education about their political rights and either do not understand or have faith in the secrecy of their ballots, making it likely that factional leaders will be able to control how they vote.

The report also explains how factions have used force and deception to collect thousands of voting cards from civilians to use in nominating political candidates, including presidential candidates. The tally of registered voters in Afghanistan, over 10.5 million in an overall population of 26 million, is now believed to be significantly inaccurate, the result of widespread multiple registration by voters. As explained here, 
pronouncements by Afghan and international officials boasting that 40 percent of registered voters are women ignores the likelihood that tens of thousands of women have been registered more than once (some believing their voting card would entitle them to benefits or food rations), and masks regional variation in the figures, including data from some southern provinces showing that less than 10 percent of those registered are women. Several election officials in Kabul acknowledged to Human Rights Watch in late September that the number of Afghans expected to vote on October 9 could range as low as 5 to 7 million.

In summary, the report describes how the general behavior and continuing power of various armed factions have created an environment of fear in Afghanistan, an atmosphere of political anxiety in which many Afghans-voters, party organizers, journalists, women's activists, even government officials-are afraid to speak openly and are censoring themselves.

\section{Frustrated Hopes}

There is a sense of disappointment running through Afghanistan today. Many Afghans are sick of warlord rule and yearn for the rule of law. They are tired of government positions being held by abusive warlords, and they are insulted that the international community appears to think that these military commanders are innocuous, that they have "reformed," or that they are otherwise acceptable. Most Afghans want the warlords out of power, and are angry that Afghanistan's political processes so farincluding two Loya Jirgas (grand councils) in 2002 and 2003-have simply been legitimizing their influence.

Credible elections are seen by many Afghans as the way to transform the country from a loose set of warlord-led fiefdoms into a functioning nation with a legitimate civilian government that protects citizens' human rights. In this sense, elections are seen not only as a goal in Afghanistan-a good in and of itself-but also a means of addressing human rights issues and warlordism.

The question is whether the presidential election in 2004 (and local and parliamentary elections in 2005) will move the country closer towards that goal. As this report shows, it is likely it will not. Most signs suggest that warlordism and factional dominance will only increase.

\section{A Mistaken Sense of Complacency}

Relief is not on the way. Many politically active Afghans, including presidential candidates, say they feel unprotected-and are scared. Afghanistan is still without an 
adequately staffed professional and independent police force, and the justice system barely functions. The NATO-led International Security Assistance Force (ISAF) and various Provincial Reconstruction Teams (PRTs), international joint military-civilian teams operated by various nations in Afghanistan, have assisted in some protection efforts but have been unable to bring an overall sense of improved security across the country. The main and continuing reason for their weakness has been the inadequate number of troops made available to their operations by NATO member nations. Amazingly, because of the inadequate provision of international forces, current security plans for the presidential election include the use of deputized warlord or factional forces to guard polling stations - the very people Afghans say they're most afraid of.

The United Nations Assistance Mission in Afghanistan (UNAMA), along with several international officials in other Kabul offices, have been working hard to combat the ongoing problems, and have intervened to support numerous vulnerable persons and groups, especially in Kabul. But international officials and agencies alone are not in a position to protect the majority of politically active Afghans. Until the Afghan government can provide security throughout the country, the need for sufficient international security forces will remain.

The government of President Hamid Karzai has made efforts to address political repression and has made some important moves to sideline abusive commanders, most notably by removing Ismail Khan as governor of Herat in September and by dropping Defense Minister Fahim as his vice-presidential candidate. Karzai's office has also intervened in several cases to prevent specific abuses. But President Karzai's authority over many areas outside of Kabul is still relatively weak-because of security fears he has been unable to campaign and is a virtual prisoner of the presidential palace- and his office is unable to protect vulnerable persons in many areas outside of Kabul. And the Karzai government is itself implicated in some of the abuses, particularly in the south of the country, and may be benefiting politically from repression by others in other areas.

Meanwhile, many in the international community, including U.S. officials closely involved with situation in Afghanistan, appear to be complacent. Many falsely assume that democracy is now on the horizon. But democracy's substance-voters and candidates taking part in an electoral process free of violence and threats, against a backdrop of a system of checks and balances, an independent judiciary, and a free press-is as elusive as ever. Almost three years have passed since the 2001 Bonn Agreement installed the first post-Taliban government, and little progress has been made in laying the foundation for a functioning democratic state. 


\section{Poor Planning and Avoidable Delays}

It is not surprising that problems persist. Democratic institutions must be developed where few previously existed. Just three years ago, Afghanistan was ruled by one of the cruelest and most incompetent governments of the modern age. The new government is being built in a midst of armed conflict, massive lack of education, and stark poverty. Few in the country have a clear notion of what democracy, the rule of law, or human rights mean in practice.

Ongoing insecurity, poor strategy-making, and poor planning have only made matters worse. The overall democratization process has repeatedly stumbled over the last two years. The constitutional Loya Jirga was postponed for several months during 2003, for poorly explained reasons, and the scheduling of the presidential, parliamentary, and local elections in Afghanistan was a repeated source of confusion over the last year. National elections (joint elections for president, parliament, and local offices) were postponedtwice-and then parliamentary and local elections were moved to 2005 .

These delays, which were announced in stages in early 2004 after weeks and months of unconfirmed rumor, were justified publicly due to ongoing logistical problems, funding shortfalls, delays in implementing necessaty legislation, and continuing attacks by the Taliban on election workers and registration sites. But the core reason for delay was that the overall security situation in Afghanistan, including in areas under government control, is still not conducive to conducting free and fair elections.

The Joint Electoral Management Body (EMB), a joint U.N. and Afghan government body appointed by President Karzai to oversee and administer elections, concluded in July 2004 that neither the Afghan government nor its international partners can guarantee the security of the many candidates expected to run in parliamentary and local elections this year. The JEMB, with President Karzai's approval, decided on a compromise for 2004: a presidential election in October, with its smaller number of candidates, and parliamentary elections next year.

\section{Political Parties and the Role of Warlords}

Afghans clearly hunger to take part in the electoral process. Eighteen candidates have successfully registered to run for president, including several independent candidates not aligned with any military factions. To date, almost 70 political parties have applied to register with the government. At least 40 have successfully registered so far.

The parties vary in scope of organization, membership characteristics, and links to different factions or governmental officials: Some are comprised of former government 
officials from pre-1992 governments, including the Soviet-supported governments of Najibullah and Babrak Karmal, the government of Daoud Khan (1973-1978) and even the government of the former King of Afghanistan, Zahir Shah. Some are reincarnations of political parties from the 1960s-1980s which never held any significant political power, including various socialist and communist groups, secularist groups, and various Islamist groups. Some parties are entirely new and are headed by youth leaders.

But much of Afghanistan's political activity is being dominated by the warlord factions. There are numerous parties - the most powerful ones in fact-which are merely proxies for the various military factions, or sub-factions within them. Afghanistan's registration law prohibits parties from maintaining their own private militias, but since most militia forces have an official status as divisions or battalions under the control of the Ministry of Defense, faction "parties" can disingenuously claim that they have no private forces. The $10^{\text {th }}$ Army Division, for instance-official units under the control of the Kabul government-are actually factional forces controlled by the Ittihad-e Islami faction ("Ittihad"), which in turn is controlled by the powerful faction leader Abdul Rabb alRasul Sayyaf.

Moreover, some factions changed their party names for registration purposes, possibly to avoid running afoul of the law. Most members of Jamiat-e Islami (Jamiat), for instance, a mujahidin military force which fought against the Soviet occupation, are now organized as the political party Nehzat-e Melli. Ittihad, a Pashtun armed faction, is now known as Daw'at-e Islami. (For more information on the different factions, see Appendix A.) Parties which change their name can then disingenuously claim that they have no official link with any military faction, and claim to be independent.

To date, the political party registration office in the Afghan government has not disqualified any party on the grounds that it maintains a private militia or is linked with one. Nor have any presidential candidates been disqualified for serving as de facto militia leaders, although some candidates who applied to be registered were disqualified on technical grounds (for instance, not having the requisite 10,000 signatures for a nomination). It would not have been difficult technically for the JEMB to make factual findings that some candidates, like General Dostum, Yunis Qanooni, Mohammad Mohaqqiq, and Karim Khalali, are de facto leaders of military forces, or are linked with such forces. The JEMB received numerous complaints about these candidates, including complaints about their links to militias. But political concerns (if not outright fear of the candidates on the part of JEMB officials) seem to have inhibited them. 


\section{Recommendations}

The Afghan government and its international partners need to act fast. Although the current election, which is not hotly contested, may pass without a serious political crisis, this should not mask the fact that the country remains in a human rights crisis. With far more heated parliamentary elections scheduled for next year, a serious political crisis that greatly exacerbates the already critical human rights situation is a serious possibility in coming months. And it is difficult to overemphasize just how major a crisis it could be, as military factions compete for official positions, power, and legitimacy (not to mention parliamentary immunity). Afghanistan's diverse factions, who fought a bloody civil war in the early $1990 \mathrm{~s}$, are by no means easy allies of each other. This continuing military factionalism, if unchecked in coming years, could spark a new civil conflict in Afghanistan, and put at risk all of the gains and opportunities presented by the U.S.-led ouster of the Taliban in late 2001.

To address these problems, Human Rights Watch urges President Karzai and the Afghan government to continue to step up efforts to sideline abusive commanders and refrain from deal-making that would further entrench warlord rule. The government must act immediately on reports of violence, threats, or intimidation against politically active Afghans or voters and denounce abusers. It must offer full support to the work of the Afghan Independent Human Rights Commission (AIHRC), the only Afghan body currently capable of addressing serious human rights abuses.

The United States should clarify its strategy in Afghanistan and make human rights protection, which will enable democratization and nation-building, a primary goal of U.S. efforts. The current strategy of supporting both the central government and regional and local warlords who resist accountability to Kabul, undermines the creation of democratic institutions and the rule of law. The United States must stop working with and supporting abusive warlords. The U.S. and other involved states should redouble efforts to assist the national government with militia disarmament, the development of an effective and rights-respecting national army and police force, while working to protect independent political actors. They must speak out against violence, threats, and intimidation against politically active Afghans and voters and denounce those responsible.

The United States, NATO member states and concerned governments, should increase cooperation with the ISAF and work to expand troop levels to ensure security throughout Afghanistan. Provincial Reconstruction Teams, where they are used in lieu of ISAF troops, should be given clearer mandates to assist with disarmament efforts and protection of vulnerable political actors and groups. 
Donor nations should increase support for human rights and democratization promotion. This should be aimed at helping the United Nations Assistance Mission in Afghanistan (UNAMA) dramatically increase its staffing levels for human rights monitoring and protection and political affairs monitoring. It should also support the work of the AIHRC in monitoring Afghanistan's human rights situation.

Donors should also prioritize additional funding for the JEMB and UNAMA to ensure they have the needed resources to administer 2005 elections. Donor nations should encourage UNAMA to facilitate a central independent monitoring body charged with observing the 2005 elections, and earmark funding for that body.

A full set of recommendations is listed in the "Recommendations" section on page 44.

\section{Note: Methodology}

This briefing paper is based on over 150 interviews conducted by Human Rights Watch in June through September 2004 in Nangahar, Paktia, Mazar-e Sharif, Kandahar and Kabul, and telephone interviews with sources in several other areas including Kunduz and Herat. Those interviewed included political organizers, candidates, civil society leaders, women's rights activists, human rights monitors, humanitarian workers, journalists, editors, doctors, school teachers, university faculty, and local and national government officials, as well as international officials, including diplomatic staff and officials and staff at UNAMA, UNHCR, and various international NGOs. With a few exceptions, the Afghans interviewed indicated that they did not want their names to be used in conjunction with their testimony. Many international officials interviewed also preferred not to be identified. Accordingly, this report does not quote those sources by name, and in most cases uses initials which do not correspond to actual names. 


\section{Background}

\section{The Bonn Process}

Afghanistan's current political process is based on the December 2001 Bonn Agreement, an accord signed by representatives of the militia forces who fought with the U.S.-led coalition against the Taliban, representatives of the former King of Afghanistan, Zahir Shah, and representatives of various other exiled Afghan groups. The agreement brought Hamid Karzai to power as the first interim leader of Afghanistan. Under the provisions of the agreement, an Emergency Loya Jirga (grand council) met in June 2002 to pick a two year transitional government. At that meeting, Hamid Karzai was chosen as President of Afghanistan. A Constitutional Loya Jirga was then convened in December 2003 to approve a new constitution and governmental structure.

According to the Bonn plan, democratic elections-for national and local governmental offices-were then supposed to occur in June 2004. The Bonn Agreement also specified, among other things, that military forces occupying Kabul city as of December 2001 had to withdraw from the city, and that forces belonging to each of the militias would either disarm or unify under the command of the head of the government, President Hamid Karzai.

Over the last two-and-a-half years there has been progress in several areas. The Afghan government has gradually re-built some of the apparatus of state power in Kabul. Development efforts have begun in provinces outside of Kabul, including construction of roads, schools, and hospitals, contributing to the growth of Afghanistan's economy. And although the majority of school age girls remain without adequate educational opportunities, millions of girls have returned to school, and universities are functioning. Training has begun of a new Afghan army and central police force. An Afghan Independent Human Rights Commission, called for by the Bonn Agreement, was founded and has begun to expand its activities. Limited legal reform processes and training of judges and lawyers have begun.

But Afghanistan's political development has remained stagnant, as many of the Bonn Agreement's most important provisions have been either forgotten or ignored. Militia forces occupying Kabul were never withdrawn from the city, no significant disarmament of militia forces nationwide has taken place (demobilization has been reduced to a goal of less than 40 percent, which will not come close to being met), and many militia leaders have retained their autonomous leadership over what are essentially private armies. Many of the country's various militia forces have fortified their strength. The national Loya Jirgas were held, and a constitution approved, but both processes were 
marked by wide-spread threats and political repression by warlord factions, as Human Rights Watch has documented in past reports. ${ }^{1}$

\section{Factions and local autonomy}

Worse still, Afghanistan's militias remain highly factionalized and autonomous. Officially, all existing military forces are unified under and responsible to the central government, but in reality most forces are controlled by various regional commanders. Most sub-commanders around the country are loyal first to other regional factional leaders, who then maintain varying degrees of overall loyalty to Karzai.

The minister of defense, Mohammad Qasim Fahim, is himself a factional leader-the main commander of the Jamiat-e Islami faction and the allied Shura-e Nazar-and has resisted many efforts to replace Jamiat and Shura-e Nazar commanders whom he appointed to high-level positions in the ministry.2 (Because of General Fahim's continuing recalcitrance, the concept of a unified military under Karzai's command remains impossible, conceptually and in practice.)

Recently, President Karzai resisted choosing Fahim to run as his vice-presidential candidate in the upcoming election, although under pressure from Jamiat to do so. But Fahim and other commanders like him remain strong, and their acquiescence to Karzai's rule seems based more on comity than obedience.

Over the last two-and-a-half years, many of President Karzai's orders have been defied or ignored by commanders, including General Fahim. In most provinces, local military commanders or factional leaders act autonomously as de facto government leaders. Most of them have little tolerance for political freedoms, and use their localized control of army and police to intimidate opponents.

There are occasionally shifts in local power-some of them quite important. For instance, Ismail Khan, the commander and governor of western city of Herat, was fired in September 2004 by President Karzai. And progress has been made in some areas on cantonment of heavy weapons held by factional forces. But most areas in Afghanistan

\footnotetext{
1 "Afghanistan: Return of the Warlords," A Human Rights Watch Briefing Paper, June 2002, at http://www.hrw.org/backgrounder/asia/afghanistan/warlords.htm; "Afghanistan's Bonn Agreement One Year Later: A Catalog of Missed Opportunities," A Human Rights Watch Briefing Paper, December 2002, available at http://www.hrw.org/press/2002/12/afghan1205.htm.

${ }^{2}$ For more information on Jamiat-e Islami, Shura-e Nazar, and other factions, see Appendix A.
} 
remain firmly under warlord rule. Disarmament efforts have essentially failed in most parts of the county.

In a few small areas in the south and southeast, where military operations continue, there is essentially no governmental structure at all. A few areas in Zabul and Kunar are essentially under the control of Taliban and insurgent forces.

In sum, Afghanistan today resembles more a loose confederation of small fiefdoms than a unified sovereign nation. Specific conditions in each region and province vary, but the overarching characteristic across the country is the same: de facto control of local governance lies with militarized faction leaders.

Afghanistan's poor security situation is often blamed entirely on the Taliban and other insurgent forces, although in reality many districts are insecure because of violence and instability caused by factions ostensibly affiliated with the government.

For instance, factional violence between rival warlord groups led to the suspension of U.N. and NGO humanitarian operations in Herat in September, and ongoing factional rivalries continue to impede aid delivery and development in several provinces in the north and west of the country.

Moreover, security personnel in Kabul now suspect that the June 2 killing of five aid workers with Médecins Sans Frontières (MSF, Doctors Without Borders), which was first thought to be carried out by Taliban forces, was in fact carried out by a local autonomous militia. ${ }^{3}$ The killings led to MSF's decision to pull out of Afghanistan in late July, a momentous decision given that MSF worked in Afghanistan through the worst violence of the early 1990 's.

In a public statement in late July, MSF said: "Although government officials have presented MSF with credible evidence that local commanders conducted the attack, they have neither detained nor publicly called for their arrest. The lack of government response to the killings represents a failure of responsibility and an inadequate commitment to the safety of aid workers on its soil.".4

\footnotetext{
${ }^{3}$ Human Rights Watch interviews with U.N. and NGO security of ficials, Kabul, September 21, 2004; Human Rights Watch interview with security officials, Mazar-e Sharif, August 15, 2004.

"Médecins Sans Frontières, "MSF withdraws from Afghanistan following killing, threats and insecurity," Press Release, July 30, 2004.
} 
The main military factions around Afghanistan include:

- Jamiat-e Islami-yi Afghanistan (hereafter "Jamiat")/Sbura-e Nazar/Nehzat-e Melli

- Ittibad-i Islami Bara-yi Azadi Afghanistan (hereafter "Ittihad")/Daw'at-e Islami

- Hezb-e Wabdat-e Islami-yi Afghanistan (hereafter "Wahdat")

- Junbisb-e Milli-yi Islami-yi Afgbanistan (hereafter "Junbish")

- Harakat-e Islami-yi Afghanistan (hereafter "Harakat")

- Durrani Pashtun tribal militias, based in and around Kandahar

- Forces based in and around Herat previously loyal to Ismail Khan (in flux)

- Taliban and Hezb-e Islami insurgent forces

Taken together, these factions control the majority of Afghanistan outside of Kabul. The Afghan National Army-a small set of divisions newly trained and under Karzai's control-have been deployed to some areas, including the cities of Jalalabad, Khost, Gardez, and Herat, but are in most cases they are outnumbered by local factional forces.

(Note: This list is not exhaustive: these are Afghanistan's most powerful and largest military parties, but there are subdivisions among these factions, and several smaller factions are not noted here. Some of the factions have registered as political parties, with new names, such as Nehzat-e Melli and Daw'at-e Islami. A description of each of the above factions appears in Appendix A.)

\section{The Presidential Candidates}

The vast majority of the 18 presidential candidates on the October 9 ballot are not running on political party tickets-even those who are in fact linked with factions.

Abdul Rashid Dostum, for instance, leader of the Junbish faction, is running for president as an independent, as are Mohammad Mohaqqiq, one of the main leaders of Wahdat, and Ahmad Shah Ahmadzai, a deputy in Ittihad/Dawat-e Islami.

Massouda Jilal, the sole woman candidate, is running as an independent, as are Homayoun Shah Assefy (the brother-in-law of former King Zahir Shah); Mahfooz Nedai, the former interim minister of Mines and Industries in President Karzai's cabinet; and Abdul Hafiz Mansoor, a writer who was affiliated earlier with Jamiat.

Some of the "independent" presidential tickets are in fact mixed: President Karzai, listed as an independent, is running on a ticket with vice-presidential candidates Ahmed Zia 
Massoud, the brother of the assassinated leader of Jamiat/Shura-e Nazar, Ahmed Shah Massoud, and Karim Khalili, a senior leader in Wahdat. Abdul Satar Sirat, a former official in Zahir Shah's government and a representative at the Bonn Agreement talks, is running as an independent with Mohammad Amin Waqad, formerly a deputy of Hezb-e Islami (the party/faction of warlord Gulbuddin Hekmatyar) as first vice-president.

The candidates officially running on political party tickets are: Yunis Qanooni, a senior leader of Jamiat/Shura-e Nazar/Nehzat-e Melli, as a member of Nehzat-e Melli; Latif Pedram, as a member of Congreh-e Melli Afghanistan; Sayyid Ishaq Gilani, as a member of Nehzat Hambastegi Melli Afghanistan; and Ghulam Farooq Nijrabi, as a member of Istiqlal Afghanistan. A complete list of presidential candidates is listed in Appendix B.

\section{Continuing buman rights problems and lack. of protection}

Most of the military factional forces in Afghanistan, listed above, are deeply involved in ongoing human rights abuses and criminal enterprises.

Human Rights Watch, Amnesty International, the Afghanistan Human Rights Commission, and other human rights and humanitarian groups have documented these abuses in past reports. ${ }^{5}$ UNAMA and the U.N. High Commissioner for Refugees have also documented many of the same problems, although without publishing all of their findings in reports.

The list of documented violations is extensive. Local military and police forces, even in Kabul, are involved in arbitrary arrests, kidnapping and extortion, and torture and extrajudicial killings of criminal suspects. Outside of Kabul, commanders and their troops in many areas are implicated in widespread rape of women and girls, rape of boys, murder, illegal detention and forced displacement, and other specific abuses against women and children, including human trafficking and forced marriage. In several areas, Human Rights Watch has documented how commanders and their troops have seized property from families and levied illegal per capita "taxes" (paid in cash or with food or goods) from local populations. In some remote areas, there are no real governmental structures or activity, only abuse and criminal enterprises by factions: trafficking in

\footnotetext{
${ }^{5}$ See "'Killing You is a Very Easy Thing For Us': Human Rights Abuses in Southeast Afghanistan," $A$ Human Rights Watch Short Report, vol. 15, no. 5 (C), July 2003, available at www.hrw.org/reports/2003/afghanistan0703; Afghan Independent Human Rights Commission, Annual Report 2003; Amnesty International, "No one listens to us and no one treats us as human beings': justice denied to women," October 2003 and "Out of sight, out of mind: the fate of the Afghan returnees," June 2003.
} 
opium, smuggling of duty-free goods into Pakistan, and smuggling of natural resources or antiquities exploited from government-owned land.

In cities, militias are relatively less audacious, but abuses do occur-including extortion and harassment or sexual attacks against women and girls. High-level commanders in Kabul, Kandahar, Herat, and other cities have been directly involved in property seizures and forced displacement.

Women and girls bear some of the worst effects of these abuses. Conditions overall for women in Afghanistan are better than under the Taliban, but women and girls continue to face severe governmental and social discrimination. Soldiers and police routinely harass women and girls, even in Kabul city. Many women and girls are still afraid to remove the burqa, fearing harassment from factional forces. And because soldiers are targeting women and girls, many are staying indoors, especially in rural areas; violence is making it difficult for them to attend school, go to work, or actively participate in the country's reconstruction. The majority of school-age girls in Afghanistan are not enjoying adequate educational opportunities. 


\section{Threats and General Political Repression}

Human Rights Watch has conducted research in Kabul and almost every region of Afghanistan, consisting of interviews with political organizers and candidates, women activists, voters, human rights monitors, teachers, university faculty, doctors, medical staff, local journalists, local government officials, and JEMB and UNAMA local and international staff.

In almost every instance, interviewees have admitted that the political climate in Afghanistan remains factionalized and repressive, and that local military leaderswarlords-continue to post a serious threat to the free exercise of political rights.

Of course, the situation is not uniform. In some areas, partial governmental reform has been undertaken, and there are some promising openings around the country for independent political activity. In Khost city, for instance, some civil society groups and political parties have been able to organize, and journalists generally operate without restrictions. ${ }^{6}$ And as noted in more detail below, in the city of Mazar-e Sharif, although the Jamiat and Junbish factions have taken control of most governmental offices, several publications, political parties, and civil society groups are operating largely freely, though they have faced some harassment. And in Kabul itself, there is a large degree of political freedom and free publications, although many political organizers and journalists continue to censor themselves for fear of angering factional leaders.

In most of the country, however, and especially rural areas, there remains a high degree of political repression, and politically active Afghans in every region reported that they regularly censor themselves for fear that they might face threats or violence at the hands of factional leaders. The Taliban and other insurgent groups are still considered a serious threat in some southern and southeastern provinces, but most Afghans told Human Rights Watch they primarily fear threats and violence by local armed groups and militias-not the Taliban. And many Afghans, including many women, told Human Rights Watch that they expect the situation to grow worse before the 2005 elections.

\footnotetext{
${ }^{6}$ However, U.S.-led coalition forces have obstructed local journalists covering ongoing military activities in the Khost area. A local stringer for Reuters and the British Broadcasting Corporation (BBC) was arrested by U.S. military forces in Khost city on September 8, 2004 and interrogated at Bagram military base about his journalistic sources. (He was released the next day with an apology.) Human Rights Watch interviews with BBC staff, Kabul, September 9 and 10, 2004.
} 


\section{Regional Problems}

\section{Jalalabad and Eastern Areas}

Human Rights Watch found serious problems in the east of the country. In the eastern provinces of Nangahar and Laghman, including Nangahar's capital, Jalalabad, Afghan militia forces remain under the de facto control of military commanders, including Hazrat Ali, who cooperates with U.S. and coalition forces operating in the area, and Haji Zahir, the son of the Haji Qadir, a former mujahidin commander and member of President Karzai's cabinet who was assassinated in Kabul in 2002.

Hazrat Ali and Haji Zahir's commanders throughout the Nangahar area operate criminal enterprises and continue to engage in numerous human rights abuses, including the seizure of land and other property, kidnapping civilians for ransom, and extorting money - as Human Rights Watch has previously documented. ${ }^{7}$ As noted below, U.S. and coalition forces continue to cooperate with these forces in operations against the Taliban and other insurgent groups.

The governor in Nangahar, appointed by President Karzai, Haji Din Mohammad, remains powerless to stop the worst effects of the factional abuses-even those of forces under Haji Zahir, who is allied with him and with the Karzai government. Two of Hazrat Ali's most infamous commanders, Commander Musa and Commander Sami (whose abuses have been documented by both Human Rights Watch and the AIHRC) have continued to operate with impunity. Complaints about militia forces committing land seizures, car thefts, and arbitrary arrests continue to be collected by the AIHRC.

Hazrat Ali and Haji Zahir's forces have both been involved in political abuses, including past threats against Loya Jirga candidates and purchasing of votes. Human Rights Watch received repeated and consistent evidence in 2002 and 2003 about Loya Jirga candidates being threatened during both conventions' delegate elections, both directly by factional representatives and indirectly, for instance, by receiving anonymous threatening telephone calls. UNAMA local staff reported during the 2003 election that several Loya Jirga candidates were intimidated by factional agents-some of whom were leaving bullets at the doors of candidates' houses, or threatening notes. One female candidate withdrew her candidacy in December 2003 after bullets were left in front of her house.

\footnotetext{
'See "Killing You is a Very Easy Thing For Us": Human Rights Abuses in Southeast Afghanistan, $A$ Human Rights Watch Short Report, vol. 15, no. 5 (C), July 2003, available at www.hrw.org/reports/2003/afghanistan0703.

${ }^{8}$ Human Rights Watch interview with AIHRC official, Kabul, September 23, 2004.
} 
An Afghan UNAMA official explained that "[The threats are] so that they [the candidates] will understand the message and stay away from the political process."

Political party organizers based in the east, especially women, continue to complain to Human Rights Watch, UNAMA, and the AIHRC about the factions' dominance. Most say that they expect the militia forces to instruct persons to vote for the candidate they ultimately support-whether it is a factional leader, or Karzai. One organizer, O.S., said:

During the previous two occasions when people had to choose their representatives, for the Loya Jirgas, they were forced or intimidated, in one way or another, to vote for certain individuals. People had no freedom of expression and we had the worst form of oppression...If this situation continues and if the powers of warlords such as Hazrat Ali here [in Nangahar] are not curtailed, the elections will mean nothing. People will see them as an effort to perpetuate the current power arrangements and not as a golden opportunity to get rid of some of the bad people now in power.

In politics here today whatever the gunmen want ultimately happens. We don't know what kind of democracy this is. ${ }^{10}$

The UNAMA official also believed that there would be abuses during both elections:

Elections are being held in an atmosphere of near complete lack of rule of law. Warlordism has grown stronger and they [the local factions] are now attempting to sabotage the process of democratization so they can stay in power. The rule of the gun continues, and warlords and lower and mid-level commanders continue to commit human rights violations with impunity. ${ }^{11}$

In late September, AIHRC began receiving complaints from sources in Jalalabad that local commanders under Hazrat Ali and Haji Zahir were intimidating local elders,

\footnotetext{
${ }^{9}$ Human Rights Watch interview with UNAMA local staff, Jalalabad, June 1, 2004.

${ }^{10}$ Human Rights Watch interview with O.S., political active leader, Jalalabad, May 31, 2004.

"Human Rights Watch interview with UNAMA local staff, Jalalabad, June 1, 2004.
} 
warning them to vote for their preferred candidate-for some commanders, Yunis Qanooni; for others, Karzai. ${ }^{12}$

To be sure, several political parties are now operating in Jalalabad city-some deeply opposed to the local factions or to Karzai. Some have even been able to hold public rallies. The commanders have not attempted to dominate completely the political process and stop all independent activity.

But the overall atmosphere in the east is still clearly marked by fear. Those who organize remain fearful of criticizing the authorities. Party leaders can make critical remarks about President Karzai and about warlordism generally, but they still appear to be afraid of openly criticizing local factional leaders by name. Moreover, many do not feel that can operate openly outside of the city.

Several independent leaders in Jalalabad said they were afraid to give public interviews to Human Rights Watch or the media.

"The security situation is very bad," one organizer, I.M.S., told Human Rights Watch.

Without making it safer for ordinary Afghans to engage in political mobilization, there can hardly be any chances of holding democratic elections... They [the military factions] have a track record of ruling by gun-and with a vengeance - so we do not expect them to become fullscale democrats overnight.

I.M.S. said he expected both the October 9 elections and next year's parliamentary elections to be dominated by the factional leaders:

In fact, the elections for the parliament will be worse because, in the absence of credible DDR [disarmament, demobilization, and reintegration of militia forces] and international peacekeepers, the warlords will yet have another chance to terrorize their unarmed political rivals, and the general public. ${ }^{13}$

\footnotetext{
${ }^{12}$ Human Rights Watch interview with AIHRC official, Kabul, September 23, 2004.

${ }^{13}$ Human Rights Watch interview with I.M.S., Jalalabad, June 1, 2004.
} 
Threats and harassment have occurred though the year. In June, after receiving threats my mail at her office, a women's rights activist was stopped in front of her home in Jalalabad by three gunmen in a car, likely under Hazrat Ali's command. ${ }^{14}$ Around the same time, a human rights NGO researcher was arrested by Sami, a relative of Hazrat $\mathrm{Ali}$, and interrogated by him and approximately seven or eight other police, who asked the researcher, among other things, what he was doing in Jalalabad, who he worked for, and what kind of information he was gathering. He was released after a few hours, after UNAMA officials intervened and high level government officials called Hazrat Ali from Kabul. ${ }^{15}$

Afghan journalists based in Nangahar told Human Rights Watch in June and August of specific threats made against them by factional commanders after they wrote critical stories about military and police forces in Jalalabad, and about being threatened not to report on news stories involving abuses by local Afghan forces. ${ }^{16}$

Human Rights Watch received evidence that at least two openly active political parties and their members have faced threats in Jalalabad in 2004: the Nehzat Hambastegi Melli of Sayyid Ishaq Gilani, and the Afghan Millat party and Anwar-ul-Haq Ahadi (a Karzai supporter and the head of the Afghanistan Central Bank). According to credible sources who refused to be identified for security reasons, posters of Gilani's party were illegally torn down in April by local police forces and some of the persons displaying them were threatened not to display them in the future. Around the same time, anonymous letters were distributed in Surkh Rod district in Nangahar alleging Ahadi was a "western crony" and warning locals not to associate with the Millat party or "otherwise face consequences."'17

Gilani and Ahadi are well-established and powerful political figures in Afghanistan. The fact that their parties are facing harassment suggests that the conditions facing smaller

\footnotetext{
${ }^{14}$ Human Rights Watch interview with T.A., Jalalabad, August 29, 2004.

${ }^{15}$ Case report on file with Human Rights Watch.

${ }^{16}$ Human Rights Watch interview with H.J., journalist from Nangahar, Kabul, August 28, 2004; Human Rights Watch interview with D.A., media producer managing staff in Jalalabad, August 12, 2004; Human Rights Watch interview with A.L.P. and R.W., Afghan journalists from Nangahar, Kabul, August 5, 2003; Human Rights Watch interviews with group of local journalists, Jalalabad, June 1, 2004.

${ }^{17}$ Human Rights Watch interviews with I.E. and L.P.E., Jalalabad, May 31, 2004.
} 
parties are likely even worse. Human Rights Watch confirmed that as of August, some political parties are still organizing clandestinely in Jalalabad, afraid of the local factions. ${ }^{18}$

Some organizers in the east have already given up. Human Rights Watch interviewed some politically active men and women from the east who had stopped organizing altogether or decided there was no point in standing as candidates in the parliamentary elections. One activist described the hopelessness of the political scene as he saw it:

\begin{abstract}
Suppose I want to be a candidate [for parliament] and have the best of the credentials, backed by extensive popular support. I can never expect to win against [for instance] the brother of a local commander, who can intimidate everybody, and will eventually win by using a mix of intimidation and purchasing votes. ${ }^{19}$
\end{abstract}

The presence of a local PRT, operated by the United States, has done little to improve the situation. The PRT has helped the overall security situation, and some progress has been made on disarming local militias and cantoning heavy weapons. PRT representatives have also intervened to assist vulnerable groups and persons in some cases. But several Afghans in the east told Human Rights Watch they were skeptical about the relationship between U.S. forces stationed in the east and Hazrat Ali and Haji Zahir. According to several sources, sub-commanders around Nangahar have threatened locals that they can be arrested and sent by U.S. troops to the detention facility at Guantanamo Bay Naval Base in Cuba if they do not comply with their demands. O.S., quoted above, told Human Rights Watch:

One of the major sources of power and authority for Hazrat Ali and his gang is his close relations with the U.S. military and intelligence. He has successfully used this relationship to harm and intimidate his political rivals. He has arrested people and constantly threatens them with sending them to Guantanamo. Al-Qaeda has become a source of blackmail in the hands of these individuals. ${ }^{20}$

\footnotetext{
${ }^{18}$ Human Rights Watch interview with A.Q.M., political party leader, August 8, 2004; Human Rights Watch interview with M.U., political party leader, Kabul, August 29.

${ }^{19}$ Human Rights Watch interview with N.G., political organizer, Jalalabad, June 1, 2004.

${ }^{20}$ Human Rights Watch interview with O.S., political active leader, Jalalabad, May 31, 2004.
} 
Several districts in the east have also suffered from irregularities during the voter registration process. The joint UNAMA and AIHRC political rights verification team in the east received complaints in July about government officials in Jalalabad city and Shinwar district confiscating voting cards by force, presumably to use for nominating political candidates in the future. The team also documented cases of commanders in Laghman province, near Jalalabad, pressuring local mullahs to issue directives that women could not register to vote. ${ }^{21}$

Of course, all of the problems outlined above have been exacerbated by ongoing threats against the election process by insurgent Taliban and other anti-government forces operating in the east. A prominent woman government official traveling with supporters by car was attacked on a road outside Jalalabad on July 13, 2004. ${ }^{22}$ Insurgent groups have continued to carry out attacks on election workers, aimed at intimidating voters and election workers-including a June 25 attack on a bus carrying female elections workers near Jalalabad which killed three and wounded several others. ${ }^{23}$

\section{Mazar-e Sharif and Northern Provinces}

The northern city of Mazar-e Sharif has a relatively freer political environment, but there are still major problems in rural areas around the city and some abuses in the city by military factions. For the most part, military, police, and intelligence forces in the north are allied with the leader of the Junbish faction, General Rashid Dostum, or to a lesser degree with the Jamiat-allied commander Atta Mohammad or the Hezb-e Wahdat commander Mohammad Mohaqqiq. (For more on these factions, see Appendix A.)

All three of these forces have been implicated in widespread abuses against ethnic Pashtun villagers in the north in the wake of the Taliban's defeat in 2001, as Human Rights Watch has documented in a previous report. ${ }^{24}$ All three-and especially the forces of General Dostum-continue to engage in abuses.

\footnotetext{
${ }^{21}$ AIHRC-UNAMA Joint Verification of Political Rights, Second Report July 8 to August 24, 2004), p. 5.

${ }^{22}$ Human Rights Watch interview with A.H., Kabul, August 23, 2004.

23 "Third Afghan Woman Poll Worker Dies of Wounds," Reuters, July 4, 2004; "Women Killed in Afghan Bus Attack," BBC online, June 26, 2004.

${ }^{24}$ Se Human Rights Watch, "Paying for the Taliban's Crimes: Abuses Against Ethnic Pashtuns in Northern Afghanistan," A Human Rights Watch Short Report, vol. 14, no. 2(c), n. 13, available at http://www.hrw.org/reports/2002/afghan2/.
} 
Human Rights Watch has received recent evidence of forces in several districts engaging in land and property seizures, looting, and extortion or "per capita tax."25 Abuses are reportedly particularly bad in the Junbish controlled districts of Jawzjan, Sar-e Pol, and Faryab, where local commanders have repeatedly defied the Karzai government and prevented Karzai's appointed governors from taking up their posts.

The three factions are also engaging in ongoing political repression. According to numerous observers with the joint UNAMA-AIHRC political rights verification team, as well as NGO and U.N. officials, Junbish, Jamiat and Wahdat (Mohaqqiq) commanders have already threatened local leaders to ensure that local populations vote as they command. ${ }^{26}$ Representatives from several areas confirmed this. ${ }^{27}$ The UNAMA-AIHRC team has also confirmed several cases of commanders using false pretenses or outright force to compel registered voters to hand over their cards to the factions, presumably so they could be photocopied for use in nominating factional candidates. ${ }^{28}$

JEMB, UNAMA, and AIHRC staff working in Sar-e Pol, Faryab, Jawzjan, and Samangan provinces confirmed cases of voter card confiscation and of local leaders being instructed how to vote. ${ }^{29}$ Observers familiar with Samangan said that the local commander there, Ahmed Khan, would deliver votes for Junbish, while in Sar-e Pol the votes would be controlled by a local warlord there, Commander Kamal. ${ }^{30}$ A politically active organizer from Jawzjan, describing the abuses there, said the local Junbish commander there, Commander Fakeer, would likely control the process. He added that most voters and organizers were unable to publicly complain about the situation or raise confirms with media or observers:

${ }^{25}$ Human Rights Watch interview with senior UNHCR officials, Kabul, August 19, 2004; Human Rights Watch interview with L.Z., Afghan journalist who documented "per capita" tax in Sar-e Pol and Balkh, Mazar-e Sharif, August 16, 2004; Human Rights Watch interviews with AIHRC-UNAMA political rights verification team officials, Mazar-e Sharif, August 16, 2004; Human Rights Watch interview with R.G., community leader from Jawzjan, Kabul, August 10, 2004.

${ }^{26}$ Human Rights Watch interviews with AIHRC-UNAMA political rights verification team officials and staff, Mazar-e Sharif, August 15 and 16, 2004.

${ }^{27}$ Human Rights Watch interviews with group of local political party organizers from Jawzjan, Faryab, Sar-e Pol and Samangan, August 17, 2004.

${ }^{28} \mathrm{Ibid}$.

${ }^{29}$ Human Rights Watch interviews with local UNAMA staff, Mazar-e Sharif, August 16, 2004; Human Rights Watch telephone interview with JEMB staff from northern province, August 17, 2004; Human Rights Watch interview with R.G., Kabul, August 10, 2004.

${ }^{30}$ Human Rights Watch interviews with UNAMA and AIHRC staff and officials, Mazar-e Sharif, August 16, 2004. 
In Jawzjan, everyone says they support Dostum in public. In private they know he has done many criminal things and buried many people in the ground. So they say one thing in public and another thing in private. They say they support Dostum but really they despise him. ${ }^{31}$

Observers also expressed concern to Human Rights Watch that Jamiat and Wahdat commanders in the north would threaten or bribe local elders and voters in rural areas they control, to ensure they would vote as told. ${ }^{32}$

Numerous staff and officials in the AIHRC and UNAMA political rights verification team stated that in most villages people would vote as told. And NGO workers conducting election awareness programs say that most voters simply did not understand the secrecy of the ballot. One trainer told Human Rights Watch, "In seminars, we emphasize a lot, that if commanders give you money say, yes, you will vote for them, but when you go in the voting room, do what you like. Vote according to your heart." ${ }^{\prime 33}$ But in most areas, voters have not received adequate information about voting, do not believe the ballots are really secret, or simply do not understand the concept of secret ballots. "In the villages, there are serious problems," said one official. "Some Afghans understand what their political rights are, but others don't, and will vote as theiy're told to vote." A senior official in UNAMA said:

In many villages, people will follow their elders and vote as the elders tell them. The factions have spies and representatives who can pay the elders in all these areas and can figure out what is going on, and easily verify what the elders say and do. Junbish's intelligence agents are especially good at this. When the elders are given a choice-taking a little money or risking their life, the elder will take the money. Even Karzai could benefit from this system. Since some of the Jamiat commanders in this area will probably support him, their intimidation will get him votes. 34

\footnotetext{
${ }^{31}$ Human Rights Watch interview with R.G., Kabul, August 10, 2004.

${ }^{32}$ Human Rights Watch interviews with UNAMA and AIHRC staff and officials, Mazar-e Sharif, August 16, 2004.

${ }^{33}$ Human Rights Watch interview with T.R., Mazar-e-Sharif, August 16, 2004.

${ }^{34}$ Human Rights Watch interview with UNAMA official, Mazar-e Sharif, August 15 and 16, 2004.
}

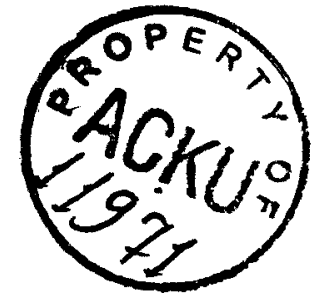


Even in the city of Mazar-e Sharif, where political parties and journalists have been freer to organize, problems persist. Several parties non-aligned with the factions have local representatives in the north, but these parties keep a relatively low profile. Several party representatives told Human Rights Watch that they were harassed by factions in 2002 and 2003, threatened with death if they publicly criticized faction leaders. Party leaders said they could not criticize local factional leaders openly now, and that if they did, their lives would be in danger.

S.S., a local civil society organizer, told Human Rights Watch:

There is no political freedom here because people are afraid. In the past, the commanders committed many crimes against the people. If I asked publicly, for instance, on a local television show, "Why aren't Mohaqqiq, Dostum, and Malik [an autonomous commander west of Mazar-e Sharif] arrested and put on trial, the commanders would kill...There is no real policing here. Anyone can kill anyone at any time, and the crimes would never be solved..$^{35}$

"Outspokenness can only lead to assassination," a U.N. political rights verification official in Mazar told Human Rights Watch. ${ }^{36}$

An Afghan journalist who earlier faced threats from both Jamiat and Junbish forces for critical reporting on abuses, summed up the atmosphere of fear:

They say: "Nobody has been killed, nobody has been arrested, nobody has been threatened." Why? Because nobody is challenging the factions. Everybody knows that they will be-be killed, arrested, or threatened-if they do. ${ }^{37}$

Even supporters of Karzai are afraid. The same journalist said that he had attempted to interview several supporters of President Karzai who refused to speak openly to him for fear they would face threats: "The spokesman for one party told me: 'If I talk to you, my life will be in danger."”

\footnotetext{
${ }^{35}$ Human Rights Watch interview with S.S., Mazar-e Sharif, August 16, 2004.

${ }^{36}$ Human Rights Watch interview with UNAMA-AIHRC political rights verification team, Mazar-e Sharif, August 16, 2004.

${ }^{37}$ Human Rights Watch interview with L.Z. Mazar-e Sharif, August 16, 2004.
} 
Women have also faced abuses and harassment. In March, Massouda Jilal was prevented from speaking at Balkh University in Mazar-e Sharif by the dean of the University, Habibullah Habib. She was also barred from speaking at an Afghan New Year celebration at the central shrine in Mazar-e Sharif, the Rowza Hazrat Ali, though government officials and other potential political candidates spoke, including Defense Minister Fahim. ${ }^{38}$

Women organizers based in the north told Human Rights Watch that the local atmosphere was politically stifling and threatening, and said they would face threats if they challenged local leaders. One woman, who was investigating a humanitarian aid project for women whose center had been taken over by local leaders, was threatened by telephone repeatedly in April 2004 and had to flee the country temporarily. ${ }^{39}$ It is possible that some politically active women in the north have joined various factions, Wahdat, Junbish, Jamiat - even those women who might be wary of the factions' militarization-believing that they might be able to pursue their political aims from within those parties. ${ }^{40}$

A politically active woman from Kunduz said the elections would be marked by abuses, and blamed the poor political situation on failures to disarm militia leaders in the north:

I do not think the elections will be very fair. It will be unfair, because the DDR [disarmament, demobilization, and reintegration] has failed in Afghanistan. Some guns were collected from people but that was symbolic, not real. These elections will also be symbolic, not real. It will just teach them about what elections are, but it will not be real. ${ }^{41}$

\section{Herat}

The human rights and political situation has been particularly poor in the western province of Herat. Human Rights Watch has previously reported extensively on political abuses in Herat and has called repeatedly on the Afghan government and its international supporters to make better efforts to stop abuses there by the local

\footnotetext{
${ }^{38}$ Human Rights Watch interview with Massouda Jilal, Kabul, August 13, 2004.

${ }^{39}$ Human Rights Watch interview with U.N. official, August 12, 2004 and Human Rights Watch interview with T.R., September 13, 2004.

${ }^{40}$ Human Rights Watch interviews with UNAMA officials, Mazar-e Sharif, August 15 and 16, 2004.

${ }^{41}$ Human Rights Watch phone interview with R.M., Kunduz, August 30, 2004.
} 
governor, Ismail Khan, and to remove him if the situation did not improve. 42 These calls went unheeded through 2003 and for most of 2004. Ismail Khan continued to maintain his own governmental administration in Herat, and defied the Karzai government repeatedly, refusing to allow local Karzai appointees to take up positions in Herat city and disobeying several of Karzai's decrees on customs revenue.

Human Rights Watch received consistent and repeated testimony through August 2004 that local military, police, and intelligence forces under Ismail Khan were continuing to threaten independent political activity and stifle free speech.

On September 11, 2004, Karzai appointed a new governor for Herat, Sayed Mohammad Khairkwa, and relieved Ismail Khan of his post (the United States had apparently refused to support a 2003 plan by Karzai to remove Ismail Khan). The same day the new governor took office, September 12, supporters of Ismail Khan attacked, looted, or burned five U.N. offices, including the headquarters of UNAMA, and AIHRC. The situation has stabilized, but Ismail Khan still controls some militia forces around Herat, and it is unclear who holds real power in Herat.

Khairkwa has already promised changes to improve political rights, but it is too soon to judge whether he has either the will or ability to allow this to happen. In any case, an overall sense of political freedom can hardly be created in four weeks before an election, particularly with Ismail Khan still resident in the city.

The repression in Herat under Ismail Khan over the last two-and-a-half years, and continuing worries about his presence in Herat, mean that many would-be political actors have good reasons to fear open and active involvement in politics. Since he was installed in power, Ismail Khan has not allowed political parties to organize or meet freely. Ismail Khan blocked two political parties from opening offices there and harassed a youth group that was attempting to organize politically. There were some small successes: The U.S.-based National Democratic Institute (NDI) started a political party capacity-building project in Herat, and a handful of parties had started to use their facilities and attend training. But the overall atmosphere remained stifling through 2004.

\footnotetext{
${ }^{42}$ See Human Rights Watch, "All Our Hopes are Crushed": Violence and Repression in Western Afghanistan, A Human Rights Watch Short Report, vol. 14, no. 7(C), October 2002, available at http://www.hrw.org/reports/2002/afghan3; Human Rights Watch, "We Want to Live as Humans": Repression of Women and Girls in Western Afghanistan," A Human Rights Watch Short Report, vol. 14, no 11(C), December 2002, available at http://www.hrw.org/reports/2002/afghnwmn1202.
} 
A political rights verification official in Herat described the environment before Ismail Khan was fired: "There is a natural engrained fear that already exists because of past repression. I have found a lot of reluctance, a lot of fear." 43 A senior UNAMA official said the same: "Herat is the worst area. There is nothing there, no political freedom, no free expression, no political activity." 44

Specific complaints were made to UNAMA and AIHRC officials in July that Ismail Khan's officials in at least two districts confiscated registration cards from voters, presumably to photocopy them for later use in nominating candidates for president or parliament. ${ }^{45}$ Said Hossain Hossaini, one of Ismail Khan's officials in Herat and the director of the Labor and Social Affairs office, also repeatedly threatened female teachers and other government workers in June, telling them they would have to vote as he instructed in the upcoming presidential and parliamentary elections or they would be dismissed. He also forced them to give him their voter registration cards. ${ }^{46}$

While Ismail Khan had publicly supported the right of women to vote, he and his forces threatened and harassed politically active women. Several activist women were forced to flee Herat, and one woman who was planning to run for parliament faced so much harassment from Hossaini and Ismail Khan that she was forced to drop her plans for a candidacy. ${ }^{47}$

Not surprisingly, there has been little free media activity in Herat from 2002 to now. An Afghan political verification official, speaking about the situation before Ismail Khan was fired, told Human Rights Watch: "There is little media freedom there, almost no independent newspapers. Even stringers for international media have faced threats." 48 Human Rights Watch documented numerous specific cases over the last two years in which officials working under Ismail Khan threatened journalists. ${ }^{49}$ Journalists in Herat

\footnotetext{
${ }^{43}$ Human Rights Watch telephone interview with Joint Verification Team official in Herat, September $8,2004$.

${ }^{44}$ Human Rights Watch interview with UNAMA official, Kabul, August 3, 2004.

${ }^{45}$ AIHRC-UNAMA Joint Verification of Political Rights, First Report (June 15 - July 7, 2004).

${ }^{46}$ Ibid., and Human Rights Watch interview with AIHRC staff, Kabul, August 3, 2004.

${ }^{47}$ Human Rights Watch telephone interview with AIHRC-UNAMA joint political rights verification official in Herat, September 8, 2004.

${ }^{48}$ Human Rights Watch interview with Joint Verification Team official, Kabul, August 1, 2004.

${ }^{49}$ Human Rights Watch has maintained regular telephone contact with several local journalists working in Herat over 2003 and 2004.
} 
were continuing to face threats from Ismail Khan's forces through August, and were regularly refraining from reporting stories which might get them into trouble with the authorities-for instance, stories about local corruption or troops engaging in human rights abuses. ${ }^{50}$

It is still unclear what effect Ismail Khan's dismissal will have. Several sources in Herat have told Human Rights Watch that most activists are not yet comfortable politically, still fearful that Ismail Khan can, somehow, return to power.

\section{Kandahar and the Southern Provinces}

The security situation in Kandahar and southern areas continues to suffer from ongoing attacks by Taliban and other insurgent groups. The insurgents, using roadside bombs, grenade attacks, and ambushes, have killed scores of aid workers, election workers, and local government staff, as well as international coalition personnel. Many rural areas remain "no-go zones" in which military operations continue against the insurgent groups. Pamphlets and so-called "night letters" are being left in many areas, presumably issued by the Taliban, threatening residents not to vote. Many voters fear continuing attacks during both the October 9 election and next year's parliamentary election. Because of security concerns, Human Rights Watch could not travel in many parts of this region and cannot report in great detail about Taliban abuses.

Abuses are not only carried out by the Taliban. There are also problems with local commanders and factions allied with the government. In the Kandahar area and southern provinces, the main military commanders from Pashtun Durrani subtribesthe Popalzais (the tribe of the Karzai family); the Alikozai, the Noorzai, and the Barakzais-continue to dominate both military and police forces and local politics. Numerous and separate sources in Kandahar, including political organizers, journalists, and U.N. and Afghan human rights monitors, told Human Rights Watch in August that local commanders and leaders have intimidated or threatened political organizers who do not support Karzai's candidacy. ${ }^{51}$

\footnotetext{
${ }^{50}$ Human Rights Watch telephone interview with Z.A.M., Afghan journalist from Herat, August 26, 2004; Human Rights Watch interview with F.S., Afghan journalist from Herat, Kabul, August 10, 2004; Human Rights Watch telephone interview with Joint Verification Team official in Herat, September 8, 2004.

${ }^{51}$ Human Rights Watch interview with N.M.J., political party representative, Kandahar, August 12, 2004; Human Rights Watch interview with I.G., political party representative, Kandahar, August 12, 2004; Human Rights Watch interview with U.T.K., political party representative, August 13; Human Rights Watch interview with A.G.; women activist, Kandahar, August 13, 2004; Human Rights Watch
} 
Some political activities have been allowed in Kandahar, but persons who have spoken critically about Karzai or the Kabul government have been threatened afterwards. Political party representatives in Kandahar told Human Rights Watch about receiving anonymous telephone calls after they criticized local leaders or Karzai, threatening them with death if they did not support Karzai. ${ }^{52}$ Party workers said that they must organize in secret to avoid harassment, or not engage in open activities critical of the local factions. As in other areas, many organizers told Human Rights Watch they avoided critical activities that might put them in danger. ${ }^{53}$

Human Rights Watch also received reports in September that Commander Muzaffruddin, a military official in Wardak province, called a meeting of elders in Wardak during the week of September 13-17 and warned them to vote for Karzai. According to an observer in the joint political rights verification project: "He told them, 'If you don't vote for Karzai, and then something happens to you, it will be your responsibility.' To the elders it was a threat, a clear threat."'54

Several observers said they expected local forces in Kandahar to use their influence during the presidential election to ensure people voted for Karzai, and would then use the same tactics to ensure that their representatives are elected to the parliament in 2005 . A journalist in Kandahar, familiar with the political situation, told Human Rights Watch:

There is an atmosphere of fear in Kandahar. If you take part in political activity against the authorities you will face threats. A lot of people who have some popularity-for instance, people from important familieswill nonetheless not put themselves forward as candidates because of the warlords. If they put themselves on the ballot for election, their lives will be in danger. Today, six months before the parliamentary elections, I can tell you that across the nation the main candidates will be warlords or people supported by warlords. 55

interview with senior AIHRC official, Kabul, September 23, 2004; Human Rights Watch interview with Afghan UNAMA staff, Kabul, September 23, 2004.

${ }^{52}$ Human Rights Watch interviews with party leaders and representatives, Kandahar, August 12 and $13,2004$.

${ }^{53}$ Human Rights Watch interviews with party leaders and representatives, Kandahar, August 12 and $13,2004$.

${ }^{54}$ Human Rights Watch interview with UNAMA staff, Kabul, September 23, 2004.

${ }^{55}$ Human Rights Watch interview with U.A., Afghan journalist, Kabul, August 3, 2004. 
Officials with the UNAMA-AIHRC political rights verification team project in Kabul offered a similar assessment. ${ }^{56}$

Women candidates, who are already struggling against societal and cultural biases, are also facing problems from the factions. A politically active woman planning to run for parliament told Human Rights Watch that she had been threatened several times and expected further harassment in the future:

[Before,] because of my independent pro-democracy and monarchist stand [support for the former King Zahir Shah], I was threatened many times, mostly through anonymous telephone calls. When I formally announce my candidacy for the parliamentary elections, I am sure that I will be pressured. I feel that I will face a lot of intimidation from those people whose power comes from the barrels of their guns. In the past the local administration here, including Karzai's brother, applied pressures to direct the political process in a certain way, and I do not expect that will change. ${ }^{57}$

Human Rights Watch also interviewed several female election workers, who expressed frustration at the poor security situation in Kandahar and said that threats of Taliban violence and rivalries between local commanders were impeding civic education and voter registration efforts. The insecurity, they said, had had a particularly negative impact on the registration of women. And according to JEMB data, the levels of female registration in southern provinces are particularly low-especially in the southern provinces of Uruzgan and Zabul, where levels were lower than 10 percent.

Human Rights Watch has previously documented repression by local commanders in southern provinces during the 2002 and 2003 Loya Jirgas.58 It appears that the past abuse has served as an effective warning to politically active Afghans not to organize now against the factions in Kandahar.

\footnotetext{
${ }^{56}$ Human Rights Watch interviews with UNAMA and AIHRC officials, Kabul, August 1 and 2, 2004.

${ }^{57}$ Human Rights Watch interview with A.G., women activist and independent candidate, Kandahar, August 13, 2004.

${ }^{58}$ See "Afghanistan: Return of the Warlords, A Human Rights Watch Briefing Paper, June 2002, at http://www.hrw.org/backgrounder/asia/afghanistan/warlords.htm.
} 


\section{Central Highlands}

Political problems are reported in the central regions of Afghanistan as well, although not as serious as in other areas. Human Rights Watch heard several complaints that commanders allied with Wahdat and Harakat factions and sub-factions have generally dominated the local political scene, ensuring that they control voting blocs for the presidential candidates Mohammad Mohaqqiq and Karim Khalili. ${ }^{59}$

Numerous international and Afghan observers told Human Rights Watch that human rights conditions were especially poor in Dai Kundi and Sharistan districts, where numerous complaints have been made with both UNAMA and President Karzai about local commanders allied with Karim Khalili, a member of President Karzai's cabinet and Karzai's choice as candidate for second vice-president.

According to political party representatives and U.N. officials interviewed by Human Rights Watch, the military forces under two commanders, Arif Dawari and Abdul Ali Touran, linked with Khalili are implicated in extortion, land and property seizures, arbitrary arrest and detention, disappearances; murders, physical assault and intimidation, and sexual abuse of women. They have also clashed with other factions. ${ }^{60}$ A U.N. security officer described the situation in Sharistan and Dai Kundi to Human Rights Watch as a "human rights nightmare." U.N. and Afghan human rights monitors have gathered evidence of the abuses and presented complaints to Afghan officials in Kabul, but-according to international officials_-Khalili blocked efforts to sideline the commanders. ${ }^{62}$

According to reports received by Human Rights Watch, confirmed with international observers in the region, in June some of Dawari's men severely beat up a Sharistan representative of the Labor and Development Party, a political party which opposes

\footnotetext{
${ }^{59}$ Human Rights Watch interview with A.H.D., representative from Dai Kundi, Kabul, August 12, 2004; Human Rights Watch interview with G.H.H., AIHRC-UNAMA political rights verification staff from central highlands, Kabul, August 2, 2004; Human Rights interview with AIHRC staff, Kabul, August 1, 2004.

${ }^{60}$ Human Rights Watch interview with senior U.N. officials, Kabul, August 19, 2004; e-mail correspondence with AIHRC-UNAMA political rights verification staff, September 2004.

${ }^{61}$ Human Rights Watch interview with a senior international security official stationed near Sharistan, Kabul, September 22, 2004.

${ }^{62}$ Ibid; Human Rights Watch interview with senior U.N. officials, Kabul, August 19, 2004; e-mail correspondence with AIHRC-UNAMA political rights verification staff, September 2004.
} 
Dawari and his faction, and ransacked and closed the party's local office in Sharistan. ${ }^{63}$ Two other party members were harassed and pushed around by troops.

\section{Kabul and Surrounding Areas}

The Kabul area, and the nearby cities of Gardez and Khost to the southeast and the city of Kunduz to the north, has fewer problems than most other areas. Political parties are organizing and opening offices in Kabul, and numerous independent and critical newspapers are operating (although not entirely freely, as shown in more detail below). Women activists and political organizers especially enjoy greater freedoms than in other areas, and have been able to meet in open forums and organize freely.

However, there are still major causes for concern. Several political parties and journalists have told Human Rights Watch about ongoing threats and harassment (in addition to fears of attacks on the election process by Taliban and other insurgent forces). Several presidential, vice-presidential, and potential parliamentary candidates have received anonymous death threats by telephone telling them not to challenge factional leaders or "the mujahidin." (More information on threats to presidential candidates is listed in the following section.)

As in other areas, election observers are concerned that voters may not understand or believe in the secrecy of the ballot. And there are signs that tribal elders in rural areas, under threat or in agreement with military factions, are ordering people how to votefor instance, for Yunis Qanooni or Karzai. On September 22, representatives of the Terezai tribe in Paktia province recorded a threatening announcement for local Khost radio in which a representative stated: "All Terezai tribespeople should vote for Hamid Karzai ... if any Terezai people vote for other candidates, the tribe will burn their houses." ${ }^{365}$

Political organizers and journalists have made numerous complaints about Sayyafs Ittihad faction and the Jamiat-e Islami/Shura-e Nazar/Nehzat-e Melli faction in

\footnotetext{
${ }^{63}$ Human Rights Watch interview with A.H.D., senior official in the Labor and Development Party, August 12, 2004; Human Rights Watch interview with a senior international security official stationed near Sharistan, Kabul, September 22, 2004.

${ }^{64}$ See section on presidential candidates below.

${ }^{65} \mathrm{~A}$ recording of the announcement was made by Agence France Presse; the representative also stated the same message to a local correspondent for $\mathrm{BBC}$, adding that those who refused to vote for Karzai would be prevented from attending the weddings and funerals of fellow tribesman. Human Rights Watch interview with BBC staff and officials in the AIHRC, September 25, 2004.
} 
particular. In one case, R.G., a politically active writer and critic in Kabul, until recently, published critical articles and took part in political meetings in Kabul. But he started receiving threats and warnings from friends that he was to be targeted for assassination by Sayyaf's Ittihad faction:

A friend came to me and told me: 'You will be a target soon. We have learned from several sources that assassins are assigned to kill you. Stop your articles, stop your writing, stop your advocacy."'66

R.G. confirmed the threat against him from other sources as well. He has since toned down his activities and is writing articles anonymously: "I do not write articles under my name anymore...I have no power against these people." 67

Another writer told Human Rights Watch that he could not publish some of his articles, critical of commanders like General Fahim, even in Kabul's freest newspapers. He said one editor asked him, rhetorically: "Do you want to get us all killed?"

Many complaints have been made by political organizers about anonymous death threats made by telephone, in most cases believed to be from troops or police associated with the dominant factions in Kabul-Jamiat, Shura-e Nazar, and Ittihad. One organizer, E.H., said he has received about "twenty or thirty" threatening calls in the last few months from people he suspects are members of factions, likely Jamiat or Ittihad. He described a typical call:

People call me on the phone, people I don't know. A few months ago, for instance, someone called me...The person on the phone threatened me, and said, "This is the call of death. [Zang ga marg.] You should get out of Kabul in 24 hours."...They say things like, "Why are you doing what you're doing? Why do you oppose the mujahidin? Why are you writing articles calling us warlords? These articles are endangering your life." These threats are from people who can't even come to see me. They don't have the balls to do anything. But I worry about Paktia [his home province]. In rural areas I carry a pistol with me. ${ }^{69}$

\footnotetext{
${ }^{66}$ Human Rights Watch interview with R.G., Kabul, August 10, 2004

${ }^{67}$ Ibid.

${ }^{68}$ Human Rights Watch interview with F.S., Kabul, August 10, 2004.

${ }^{69}$ Human Rights Watch interview with E.H., Kabul, August 9, 2004
} 
In another case, unidentified gunman fired gunshots into the window of a woman activist's home in Kabul after she had made several public statements criticizing military commanders in and around Kabul, calling for greater political participation of women in Afghan politics, and condemning several incidents of rape near Kabul and cases of trafficking of women. She plans to continue her activities, as she told Human Rights Watch: "To fear losing your life is part of living in this country."

Other organizers are pushed to curtail or stop their work. Human Rights Watch interviewed one prominent organizer in Kabul who had gone into hiding after various threats made against him-he believes by Ittihad and the Jamiat or Shura-e Nazar military commanders. ${ }^{11}$

Even officials in the government are at risk. In early August, military troops entered by force into the Kabul home of O.L.K., a senior official in the Ministry of Information and Culture, to harass, arrest or possibly kill him. Based on interviews with witnesses, Human Rights Watch believes the troops belonged to Sayyafs Ittihad faction. O.L.K. himself said:

It was Sayyafs men. This was after I had written [an article]. I wrote that the coalition with the warlords is killing chances of democratization in Afghanistan, and killing human rights. I wrote about Kabul ten years ago, about how Sayyaf had destroyed Kabul, killed 65,000 civilians, and about how his troops had forced young women into marriages. ${ }^{72}$

O.L.K said he had started carrying an automatic pistol with him, though he had never owned a gun before. While showing the pistol to a Human Rights Watch researcher in his office in a government building, he explained: "I have to protect myself. I don't know who might come through that door."'?

Everyone fears these people ["gunman" and "factions"]. Everyone knows that DDR [disarmament, demobilization, and reintegration of

\footnotetext{
${ }^{70}$ Human Rights Watch interview with M.T., Kabul, August 13, 2004.

${ }^{71}$ Human Rights Watch interview with M.U., political party leader, Kabul, August 29, 2004.

${ }^{72}$ Human Rights Watch interview with O.L.K., senior government official, Kabul, August 11, 2004.

${ }^{73}$ Ibid.
} 
militia forces] must begin; otherwise there will be no freedom, no democracy. $^{74}$

The harassment of high-level government officials has ripple effects, contributing to an atmosphere of fear. As one well-known journalist told Human Rights Watch, "When a minister doesn't have the right to freedom of expression, what about me?"'75

\section{Security of Presidential Candidates}

Human Rights Watch spoke with several of the non-aligned presidential and vicepresidential candidates, unconnected to the dominant factions in Kabul. Many voiced concerns about their safety in the lead-up to the elections-both from attacks by Taliban and other insurgent groups and from warlord factions-and said that they felt their protection was inadequate, even in Kabul. The Ministry of Interior was supposed to provide security for the candidates, but many did not receive any guards for weeks after they declared their candidacies. In any case, some said they had little faith that police could protect them from either the Taliban attacks or threats from factional groups.

Massouda Jilal and her supporters have faced harassment in some districts and received threatening telephone calls in Kabul. Dr. Nelab Mubarez, a female vice-presidential candidate with the presidential candidate Homayoun Shah Assefy, told Human Rights Watch in August that she had significant fears about her security. ${ }^{76}$

Another candidate, Latif Pedram, told Human Rights Watch that specific threats were made against him by Sayyaf's Ittihad faction. Sayyaf clearly does not like Pedram, either because Pedram embraces relatively liberal political views or because he maintained connections in the 1980 s to the communist government before joining the mujahidin. Sayyaf issued a letter around April 2004 to Ittihad members stating that Pedram was an infidel. Pedram told Human Rights Watch that Ittihad troops have come to his office twice and harassed his supporters." Pedram told UNAMA staff in September that he fears driving through parts of Kabul and nearby areas which are in the control of commanders and police officials loyal to Sayyaf. ${ }^{78}$

\footnotetext{
${ }^{74}$ Ibid.

${ }^{75}$ Human Rights Watch interview with H.G., Kabul, August 23, 2004.

${ }^{76}$ Human Rights Watch interview with Mubarez, Kabul, August 13, 2004.

${ }^{77}$ Human Rights Watch interview with Latif Pedram, Kabul, August 17, 2004.

${ }^{78}$ Human Rights Watch interview with UNAMA staff, Kabul, September 23, 2004.
} 
In late August, judges allied with Sayyaf on Afghanistan's Supreme Court wrote to the JEMB, demanding that Pedram be disqualified as a candidate because of remarks he made to the effect that polygamy was incompatible with social justice for women, which the court claimed were blasphemous. The JEMB did not respond, and they received another letter in mid September demanding that they implement the Supreme Court's order. The JEMB responded by questioning the legal grounding of the Supreme Court's demand. The affair may not proceed further, but the incident serves as another indicator of how factions in government can use their power and influence to try to stifle free political activity.

President Karzai is also still in danger. He continues to be guarded by private foreign security guards - a sign they he does not trust Afghan guards who could be provided, either because they could be infiltrated by Taliban agents or by agents of factional leaders. On September 5, 2002, he narrowly avoided being shot in an assassination attempt in Kandahar. On August 29, 2004, a bomb exploded in front of the American private security company, DynCorp, which provides bodyguards for Karzai, killing three DynCorp staff. More recently, on September 16, 2004, a rocket was fired at a compound in Gardez as Karzai's helicopter was approaching for landing, causing his trip to be cancelled.

\section{Structural Electoral Problems}

Human Rights Watch uncovered significant shortcomings in the registration and election administration process, as well as with international monitoring efforts.

\section{Registration}

The registration of voters in Afghanistan is being widely touted inside and outside of Afghanistan as a success, as up to 11 million people are expected to register by election day, including refugees in Iran and Pakistan. But the overall numbers are almost certainly inaccurate. As the non-governmental organization Afghanistan Research and Evaluation Unit (AREU) noted in a recent report, the number of registered voters in several provinces is significantly larger than the estimated population of known eligible voters. $^{79}$ While population estimates in Afghanistan, which are not based on a comprehensive census but on sampling and projected growth rates, are a source of controversy and differing opinion, the phenomenon of over-registration has occurred in several different areas in Afghanistan and exists even when measured against the highest population estimates for those areas. No data is yet available to estimate the number of

\footnotetext{
79 Afghanistan Research and Evaluation Unit, "Free, Fair or Flawed: Challenges for Legitimate Elections in Afghanistan," September 2004, available at: http://www.areu.org.af.
} 
multiple registered voters, but many officials in UNAMA, JEMB, AIHRC and Afghan and international NGOs told Human Rights Watch that they believe the overall number of registered voters is vastly inflated. Several election officials in Kabul told Human Rights Watch in late September that the number of Afghans expected to vote on October 9 could range as low as 5 to 7 million. ${ }^{80}$

Human Rights Watch, as well as other observers and journalists, have found that in most provinces it is easy to find men and women who admit that they have registered more than once. The motives vary. For instance, some students at Kabul University told Human Rights Watch they registered a second time in Kabul after registering in their home provinces earlier. (One student said she got a second card because she did not like the photograph on her first one.) Observers around Mazar-e Sharif told Human Rights Watch of women voters in rural areas who thought the voting card was a ration card, and registered multiple times believing they could get multiple rations of food aid. UNAMA, JEMB, and AIHRC also received numerous complaints from provinces of people registering multiple times believing they could sell their cards to political parties, who would then presumably photocopy them for use in nominating candidates (a potential presidential candidate needs 10,000 photocopied voter cards; a parliamentary candidate needs 500). It is also possible the factions themselves encouraged supporters to register multiple times, under different names, to obtain more cards, to use for nominations in the future.

The Afghan government has publicly underplayed the problem. When asked about multiple registration at a press conference with U.S. Secretary of Defense Donald Rumsfeld in Kabul the August 11, Karzai said:

As a matter of fact, it doesn't bother me. If Afghans have two registration cards and if they would like to vote twice, well, welcome. This is an exercise in democracy. Let them exercise it twice. But it will not have an impact on the elections. If somebody gives me three cards, I will take it and will go and vote. But my choice in voting will be the same. We are beginning an exercise. We cannot be perfect.

He correctly noted later, at the end of the same press conference, that voters' hands would be marked with an indelible ink when they voted, and that persons with ink already on their hands would not be allowed to vote again.

${ }^{80}$ Human Rights Watch interviews with UNAMA and NGO observation team officials, Kabul, September 22 and 23, 2004. 
It is not clear how much multiple voting may occur on election day. Voter registration is one safeguard against voter fraud, and the voting card one of the tools. But now the only remaining safeguard left against multiple voting will be the marking of voters' hands with indelible ink when they vote. Unfortunately, there may be ways around this safeguard as well-from bribing officials to allow voters with marked hands to vote again to various methods allegedly available to remove the ink from voters' hands on election day.

\section{Monitoring and Election Administration}

The presidential election is going forward with inadequate international election monitoring and staffing for polling sites. The election is certain to be affected by a serious shortfall in staffing for the approximately 5,000 polling sites. It was originally estimated that 125,000 staff would need to be hired. As of early September, a month before the elections, almost 100,000 poll workers still had to be hired and trained-an essentially impossible task.

One senior international NGO official working on election monitoring issues told Human Rights Watch in late August:

We are 100,000 staff short. The elections are only six weeks away and
there is no polling manual. It is a poor process. You need
knowledgeable officials in the polling stations. If they get a challenge,
will they have the knowledge and authority to resolve it? Lots of people
are complaining that their voter registration cards were taken from
them...10 million voters registered, how many will show up? 8 million,
4 million? We don't know. Are these inflated figures, will security play
a role? People don't know. There are rumors that the voter registration
cards are food ration cards. Are these elections really legitimate?8

As of the last week of September, hiring has accelerated, but election officials admitted to Human Rights Watch that it was likely that significantly fewer staff would be hired than the planned $125,000 .^{82}$ There are certain to be serious problems at all polling sites that are understaffed or have poorly trained staff.

\footnotetext{
${ }^{81}$ Human Rights Watch interview with D.L., August 26, 2004.

${ }^{82}$ Human Rights Watch interview with JEMB officials, Kabul, September 21 and 22, 2004.
} 
The staffing problem is especially acute with women. Each polling site is supposed to have separate stations for women, staffed by female poll workers. In September, the JEMB gave up on the goal of recruiting the adequate numbers of female staff (half of whom must be literate under election laws), and are now training and appointing elderly men to serve at some of the voting sites for women, on the theory that sensitivities about women mingling with men, in more conservative areas, will thereby be assuaged. Nevertheless, given those same sensitivities, the shortfall in female staff could seriously undermine women's ability to exercise their right to vote and participate equally in the election.

Monitoring efforts are also anemic. UNAMA and AIHRC launched a joint project for "verification of political rights" in June and will monitor the political process through the October 9 election and next year's parliamentary elections. This project is not comprehensive, however: it involves less than one hundred staff.

The Organization for Security and Cooperation in Europe (OSCE), which was asked by the Kabul government to help monitor the elections, decided in late July that it could not send an observation team. An OSCE Exploratory Mission Report by the Office for Democratic Institutions and Human Rights (ODIHR) concluded that "the present conditions in Afghanistan are significantly below the minimum regarded by OSCE/ODIHR as necessary for credible election observation..." Remarkably, the report recommended that the OSCE should avoid observing the election because it was likely that the monitoring process would uncover substantial flaws and "challenge public and international confidence in the process." In essence, the OSCE concluded in advance it would be critical of the process and therefore decided not to send a monitoring team because the criticism might not be "fair, helpful, or constructive."

The European Union also decided against sending monitors for the presidential elections, although it will, like the OSCE, send a smaller representative team to observe a few limited posts, in urban areas, and not make a comprehensive report or observe on a national basis.

Part of the problem is security: ongoing threats by the Taliban and insurgents have forced international agencies to lessen their activities in Afghanistan. But there is also a lack of will and leadership by the JEMB, UNAMA, and among U.S. and international actors in Kabul, to take the lead on organizing monitoring and observation effort.

${ }^{83}$ Report of the OSCE/ODIHR Exploratory Mission to Afghanistan, July 21, 2004, on file with Human Rights Watch. 
In October, the final monitoring effort will consist of a patchwork of international observers sponsored by the Asia Foundation, various NGO observers, and representatives sent by various foreign embassies in Kabul. Afghan observers from registered political parties will also monitor polling sites. A coalition of Afghanistanbased NGOs are also attempting to organize and train hundreds of domestic pollwatchers; in any case, the observers can only cover about 10 to 20 percent of the approximately 5,000 polling sites and 25,000 polling stations. The majority of stations will not be observed by independent monitors-Afghan or international.

Thus, the overall international election monitoring effort in Afghanistan for the October 9 elections will be severely shorthanded, and none of the diverse monitoring teams will be in a position to make a comprehensive evaluation.

A senior JEMB official told Human Rights Watch:

There will be major flaws in the process, and everyone knows it. The context of this election means that if a real up-to-snuff election observing mission were to come to monitor, this election would be seen as flawed. ${ }^{84}$

The implications of this lack of monitoring are clear: In the absence of a proper evaluation, the election may be seen-erroneously-as a success. No election in a country in transition, with such an international profile and so much international involvement-such as in Cambodia, El Salvador, South Africa-has ever had such an anemic monitoring effort.

\footnotetext{
${ }^{84}$ Human Rights Watch interview with senior JEMB official, [GET DATE] Kabul.
} 


\section{Conclusion}

The political rights of Afghans are not being adequately protected or promoted in the run-up to the October 9 election. The overall process has been severely affected by the overriding atmosphere of threats, harassment, and fear. Because of this environment, an indeterminable number of politically active Afghans have decided against taking part in the process, and many voters are not free to enjoy their right to participate actively in politics. Many voters simply may not be able to vote as they wish, not trusting the secrecy of the ballot and fearing the consequences if they do not follow instructions.

Human Rights Watch cannot evaluate whether the problems described here mean that the overall election result will not be an expression of the popular will of the Afghan people. (It is not in our mandate or expertise to make such a conclusion.) We can only state that a significant number of human rights abuses have occurred in relation to the process, and that these abuses have severely damaged the election as a vehicle for expression of political will.

The biggest problems are yet to come. President Karzai is being challenged by several factional leaders, but most of those analyzing the elections expect him to win, even if there are some complications along the way. In fact, few of the candidates running against President Karzai actually expect they can win. Those who represent factions are likely just creating political capital for themselves to barter for positions in a future cabinet. Much of the political pressure and many of the threats reported here may thus merely be part of efforts by factions to create malleable factional voting blocs which the factions can then deliver for Karzai on election day-for a price. This is not simply bloc voting (a common enough phenomenon in most political systems), but voter control by well-armed and violent men through threats of violence and intimidation against candidates and voters alike.

The danger, therefore, is not that the election will descend into violence, but that President Karzai will enjoy a hollow victory in which he is forced to appoint an unrepresentative cabinet similar to the current one-a set of warlords and warlord proxies, with atrocious human rights records-and keep factional commanders in control of local areas outside of Kabul. This is an outcome that would create serious risks for the 2005 local and parliamentary elections, when the factions' control can be used to deliver votes for the factions' candidates.

Human Rights Watch fears that without significant and immediate changes in the overall international effort in Afghanistan, the 2005 elections will likely be marked by 
widespread political repression and violence, as factions tighten up their control of local voting blocs.

The 2005 parliamentary elections will be a significant test for democracy in Afghanistan and will determine, among other things, whether Afghan women can freely exercise their political rights. Human Rights Watch has already interviewed dozens of likely female candidates for parliament who fear harassment, violence, or retaliation from warlords if they run for office. (The political situation of women in Afghanistan is the subject of a forthcoming report by Human Rights Watch.)

There are few reasons to be optimistic. The underlying theory behind the postponement of parliamentary and local elections is that-somehow-security conditions will have improved by next year. There is little reason to expect this will be so. As things stand, the Afghan government has found it extremely difficult to secure necessary commitments for added international security forces or additional funding to implement security sector reform. And as noted above, the basic logistical preparations for administering and monitoring the October election have fallen far behind schedule; for the more complex 2005 elections, six months away, it could be even worse. There are no clear indications that major policy shifts will take place on the international level before the 2005 elections. Accordingly, it is likely that the 2005 elections will also be marked by a general lack of security and an adequate monitoring effort, creating an environment for impunity for widespread abuses.

Simply put, current democratization strategies are not working. President Karzai is attempting to sideline abusive commanders, but often blanches on the job, believing that he can weaken warlords by making deals with them-a strategy which has failed in most areas, despite succeeding in some others. The United States, as a leader in the international effort to assist Afghanistan's democratization, has failed to adequately assist President Karzai establish a fully functioning national government.

Broadly speaking, the focus of U.S. policy in Afghanistan over the past two years has been to militarily defeat remaining Taliban and insurgent forces in Afghanistan and to assist in the political and economic restructuring of the country. In practice, the U.S. military has undertaken much of the ground work for implementing this policy, but has been unable to strategize effectively. U.S. military objectives in Afghanistan now include: searching for remnants of Taliban and other anti-government forces, capturing non-Afghan terrorist leaders, assisting in political negotiations between President Hamid Karzai's government and local leaders, assisting with reconstruction and development projects in rural areas, and preventing civil conflict between rival Afghan military factions. But the means employed to reach the goals have too often been insufficient 
and inappropriate, and there is no known guide as to how these agendas are supposed to harmonize, and which take precedence over others.

Moreover, the military reconstruction effort has been thwarted by lack of resources and vision, and the U.S. military's involvement in the development sphere has created security problems for international humanitarian agencies. More fundamentally, this dual strategy has proven mutually contradictory, such as when the U.S. cooperates with or provides assistance to regional warlords who interfere with national development programs or otherwise oppose Kabul's authority.

Efforts to strengthen the government of Afghanistan, and support President Karzai's efforts to rein in factions, are clearly suffering heavily. U.S. personnel are cooperating and even supporting warlord leaders like Hazrat Ali in Jalalabad, General Dostum and Commander Atta in Mazar-e Sharif, and General Fahim in Kabul-even as the central government attempts to rein them in. At the same time, the United States has not supplied the central government in Kabul an adequate amount of assistance to train and expand a credible and professional police force and central army. The overall strategy is self-defeating and harms long-term efforts to promote the respect for human rights in Afghanistan. 


\section{Recommendations}

To the Government of Afghanistan:

- President Karzai should take all possible steps to stop intimidation, threats, and harassment of political actors and voters by factions, including those who support him. He should encourage voters and candidates-some of whom have little faith that their complaints will be heard-to report their abuses to local UNAMA, AIHRC, or JEMB offices. President Karzai should order the dismissal of any government official found by either JEMB or the joint AIHRC-UNAMA political rights verification team to have committed threats or abuses.

- To help alleviate the confusion and intimidation caused by parties and factions collecting or confiscating voter cards from registered voters, and to remove one motive for multiple registration by voters, President Karzai and his cabinet should repeal the sections of the Afghan electoral law specifying that candidates submit photocopies of Afghan voter cards to support their nominations for president, parliament, or local office.

- The government should make a new request to NATO to supply additional troops for the International Security Assistance Force (ISAF).

- The government should ask NATO and the U.N. Security Council to expand ISAF's mandate to include a central role in disarmament, demobilization, and reintegration (DDR) efforts and request that countries operating Provincial Reconstruction Teams (PRTs) integrate PRT operations into ISAF command.

- President Hamid Karzai, his cabinet, and Afghanistan's main military factions must commit themselves to meaningful implementation of DDR programs.

\section{To the United States:}

- The United States should make human rights promotion and protection a primary goal of U.S. efforts in Afghanistan, which in turn will enable democratization and nation-building processes. The United States should support Afghan government efforts to improve political freedoms, including by helping to weaken autonomous abusive commanders, redoubling efforts at militia disarmament, and increasing protection of independent political actors. 
- The United States should increase cooperation with the International Security Assistance Force and support the expansion of troop levels so that ISAF can play a greater role in providing security for the 2005 elections and security generally to enhance political freedom. ISAF troop levels, currently set to go down after the elections, should instead be increased. The U.S. should work with other NATO member states to adopt a common mandate for ISAF and PRTs, focusing on assistance with disarmament efforts and protection of vulnerable political actors and groups. Provincial Reconstruction Teams, where they are used in lieu of ISAF troops, should be given clearer mandates to assist with disarmament efforts and protection of vulnerable political actors and groups.

- The United States should immediately end all direct cash payments and other assistance by agencies of the United States to Afghan military or faction leaders or sub-leaders and discourage payments to such leaders by other sources. The Department of Defense and all intelligence-gathering agencies in Afghanistan should review their operations to ensure that U.S. cooperation with local militias, local commanders, intelligence sources, and other local entities is not being misused as a basis for extorting civilians or threatening political opponents.

- The United States should increase funding and support for training of the Afghan national army, as well as police training, to professionalize these forces. The United States should specifically increase the U.S. contribution to the Law and Order Trust Fund for Afghanistan (LOTFA).

\section{To NATO member states and other nations involved in Afghanistan:}

- Increase ISAF troop levels, which are currently set to go down after the elections.

- Adopt a common mandate for ISAF and PRTs, focusing on assistance with disarmament efforts and protection of vulnerable political actors and groups. Provincial Reconstruction Teams, where they are used in lieu of ISAF troops, should be given clearer mandates to assist with disarmament efforts and protection of vulnerable political actors and groups.

\section{To Donors:}

- Increase financial support for human rights and democratization projects, including funding for UNAMA and AIHRC human rights monitoring and reporting, and voter education projects. 
- Ensure that the JEMB and UNAMA have the necessary resources and funding to administer 2005 elections.

- Encourage UNAMA to facilitate a central independent monitoring body charged with observing the 2005 elections, and earmark funding for that body.

To the United Nations Assistance Mission in Afghanistan (UNAMA):

- Increase staffing levels for human rights and political affairs monitoring, and continue public reporting with the Afghan Independent Human Rights Commission on Afghanistan's political rights situation. To ensure that staffing increases are not delayed by bureaucratic hurdles, the hiring process should be centralized to Kabul.

- Put special emphasis on facilitating a central independent monitoring body to observe the 2005 elections.

To the Special Representative of the U.N. Secretary-General:

- Continue pressuring the Afghan government and its international partners to revitalize disarmament, demobilization, and reintegration efforts. The Special Representative should keep pressure on the United States and NATO members to increase troop contributions for ISAF and PRTs and refocus the mandates of those forces on assisting with disarmament efforts and protecting vulnerable political actors and groups. 


\section{Appendix}

\section{Appendix A: Afghanistan's Main Military Factions}

Jamiat-e Islami-yi Afghanistan (hereafter "Jamiat"), Shura-e Nazar and Nebzat-e Melli Jamiat is a predominately Tajik Islamist political party founded in the 1970s by Burhanuddin Rabbani, the President of Afghanistan from 1992-1996. Jamiat became a military faction during the Soviet occupation and later comprised the bulk of the military forces of the Rabbani government in the early 1990s. Although Rabbani was Jamiat's original official leader, Ahmad Shah Massoud, as the leader of Jamiat's military wing, was its most powerful figure. Massoud founded and led Shura-e Nazar, a military federation including other mujahidin military forces. After Massoud was assassinated, on September 9, 2001, Jamiat and Shura-e Nazar forces came under the control of his senior commanders and advisors, including Mohammad Qasim Fahim (now the Minister of Defense), Yunis Qanooni (now a presidential candidate and a member of President Karzai's cabinet until July 2004), and Dr. Abdullah (the Foreign Minister). Regional Jamiat commanders include Mohammad Atta in Mazar-e Sharif (now the Governor of Balkh) and Mohammad Daoud from Kunduz (now a senior official in the Interior Ministry). Jamiat members, some of whom have reorganized under a political title of Nehzat-e Melli, hold numerous governmental posts. Today, most Jamiat and Shura-e Nazar commanders remain allied, although there are often tensions between them.

Ittihad-i Islami Bara-yi Azadi Afghanistan (hereafter "Ittihad") also known as Daw'at-e Islami Ittihad is a predominately Pashtun faction headed by Abdul Rabb al-Rasul Sayyaf, originally a Jamiat official who founded the party in the early 1980s. Ittihad obtained assistance from Saudi Arabia throughout the war against the Soviet occupation, and Arab volunteers supported by Saudi sources fought with Sayyaf's forces and trained in Ittihad camps. Ittihad's central power base is in Paghman district, west of Kabul. Ittihad was and is allied with Jamiat. It is sometimes described as part of Shura-e Nazar. Ittihad leaders hold numerous military posts nationally, and numerous judges and governors around the country, including the governor of Kabul, Mullah Taj Mohammad, and the Chief Justice of the Supreme Court, Fazul Hadi Shinwari, are believed to have been appointed by President Karzai at the insistence of Sayyaf. Ahmad Shah Ahmadzai, one of the presidential candidates, is an Ittihad member.

Hezb-e Wabdat-e Islami-yi Afghanistan (hereafter "Wahdat")

Wahdat is a predominately Hazara faction in Afghanistan, based in central Afghanistan and comprised of several Shia parties, who united in the late 1980s. Wahdat was 
originally led by Abdul Ali Mazari (killed in 1996) and heavily supported by Iranian sources. Wahdat was allied with Jamiat and Shura-e Nazar forces in 1992 (yet fought with Ittihad in Kabul) and allied with them again after 1996 against the Taliban, but has largely remained an independent force. Wahdat is no longer a unified party. Some of its commanders are allied with Mohammad Mohaqqiq, a northern commander now running for president who served as Minister of Planning in President Karzai's cabinet until March 2004. Others are allied with Karim Khalili, one of President Karzai's vicepresidents and now a candidate for second vice president on President Karzai's ticket.

\section{Junbish-e Milli-yi Islami-yi Afghanistan (hereafter "Junbish")}

Junbish is a predominately Uzbek and Turkmen militia and political party based in northern Afghanistan, led by Abdur Rashid Dostum, a former general in the Sovietbacked Afghan army in the 1980s who turned against Kabul in the final days of the Soviet-backed government. Junbish as a militia is mostly comprised of forces from the former Soviet-backed army and various mujahidin militias from the north of the country. Most rurally based commanders in the northern provinces of Samangan, Balkh, Jowzjan, Faryab, and Baghlan provinces are allied with Junbish.

\section{Harakat-e Islami-yi Afghanistan (hereafter "Harakat"),}

Harakat was a Shia political party and mujahidin force founded in the early 1980s. The Harakat-e Islami party was headed for most of the 1980s by Mohammad Asef Mohseni (a cleric who participated in the June 2002 Loya Jirga). Harakat received substantial support from Iran in the early 1990s. Harakat, like Wahdat, is now fractured. One faction is led by Mohseni, a second splinter is led by a military commander Sayeed Hossein Anwari (now the Agricultural Minister), and a third is led by Sayeed Mohammad Ali Javeed (now the Minister of Transportation).

\section{Durrani Pashtun Tribal Militias in and around Kandabar}

In the south, in areas in and around Kandahar province, military, police, and other governmental posts are mostly controlled by Pashtun Durrani subtribes-the Popalzais (the tribe of the Karzai family), the Alikozai, and the Barakzais. These tribal forces, which fought as mujahidin forces in the 1980s, are either controlled or allied in varying degrees with President Karzai. President Karzai's brother, Ahmed Wali Karzai, controls the Popalzai forces and maintains loose control over Alikozai and Barakzai commanders and leaders, some of whom also maintain close ties to Jamiat and Shura-e Nazar.

\section{Ismail Khan's militia in and around Herat}

Until recently, western provinces in and around Herat were controlled by the militia of Ismail Khan, an Islamist mujahidin leader. Ismail Khan is loosely allied with Jamiat and 
Shura-e Nazar but has remained essentially autonomous. Until he was removed by President Karzai on September 12, 2004, he controlled almost all aspects of government and security forces in Herat and surrounding districts. He is still believed to have significant power over militia forces in the Herat area. 
Appendix B: Names of Presidential and Vice-Presidential Candidates in the October 9, 2004 Election

\section{Hamid Karzai}

Vice-presidential candidates: Ahmed Zia Massoud, Karim Khalili

Yunus Qanooni

Vice-presidential candidates: Taj Mohammed Wardak, Sayyid Husain Aalimi Balkhi

Abdul Rashid Dostum

Vice-presidential candidates: Safiqa Habibi, Wazir Mohammed

Mohammad Mohaqqiq

Vice-presidential candidates: Nasir Ahmad Insaf, Abdul Faiaz Mhiraain

Abdul Latif Pedram

Vice-presidential candidates: Haji Ahmad Nirow, Mohammed Qasim Masomi

Masooda Jilal

Vice-presidential candidates: Mir Habib Sahily, Sayid Mohammed Aaliam Amini

Ahmad Shah Ahmadzai

Vice-presidential candidates: Aminullah Shafajoo, Abdul Manna Urzgani

Sayyid Ishaq Gilani

Vice-presidential candidates: Mohammed Ismail Qasimyar, Baryali Nasraty

Abdul Satar Sirat

Vice-presidential candidates: Qazi Mohammed Amin Waqad, Abdul Qadir Amini

\section{Abdul Hafiz Mansoor}

Vice-presidential candidates: Sayid Mohammeed Iqbal Manib, Mohammed Ayub Qasimi

Homayoun Shah Assefy

Vice-presidential candidates: Abdullah Rahmatee, Dr. Nelab Mobarez 
Abdul Hasib Aryan

Vice-presidential candidates: Dil aqa Shkaib, Sayid Jahya

Said Abdul Hadi Dabir

Vice-presidential candidates: Abdul Rashid, Dad Mohammed

Abdul Hadi Khalilzai

Vice-presidential candidates: Khidai Noor Mandokhil, Khdadad Urfani

Mohammad Mahfooz Nedai

Vice-presidential candidates: Sayid Mohammed Arif Ibrahim Khil, Mohammed Hakrim

Karimi

Mohammed Ibrahim Rashid

Vice-presidential candidates: Sayid Mohammed Hadihadi, Hamid Tahiri

Ghulam Farooq Nijrabi

Vice-presidential candidates: Abdul Fatah, Abdul Hanan

Wakil Mangul

Vice-presidential candidates: Mohammed Yunus Moghil, Dina Gul

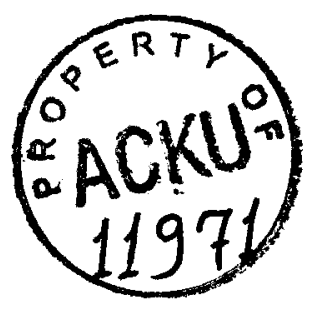

